\title{
The Holy Sacrament of Ordination - Principles and Elements of Canonical Doctrine
}

\section{Ioan COZMA*}

Abstract: The present study adds to the research dedicated to the Holy Sacrament of Ordination. The article begins with an explanation of terms, showing the difference between khirotonia and khirotesia; the first term being used for the act of introduction in the sacramental priesthood, while the second term denoted entry into the lower ranks of priesthood. Next, the study continued with a canonical assessment, in which, on the basis of sacred canons, I had shown who can administer this sacrament, as well as who the subjects of the ordination are. A particular emphasis was placed regarding the inability of women to be ordained. In the final part of the study, I have revealed what the legal and canonical effects are to the ordination mystery.

Keywords: ordination, holy canons, clergy, priesthood, women's ordination

\section{Khirotonia and Khirotesia - terminological clarification}

Ordination is the sacramental act which, through the bishop's imposition of hands and prayer, those chosen for sacerdotal ministry are

* Rev. Fr. Dr. Ioan Cozma $\mathrm{PhD}$ in oriental canon law, Romanian Orthodox Episcopate of America (Orthodox Church of America), visiting professor at Oriental Pontifical Institute in Rome. 
given the gift of priesthood with its many stages, making them capable to continue within Church the threefold ministry of Christ: sanctifying, teaching and leading.

The imposition of hands is designated by the terms khirotonia ( $\chi \varepsilon \imath \rho o \tau o v i \alpha)$ and khirotesia ( $\chi \varepsilon \imath \rho o \theta \varepsilon \sigma i \alpha)$, correspondents of verbs khirotonein ( $\chi \varepsilon \imath \rho o \tau o v \varepsilon \tilde{v} v)$ and khirotetein $(\chi \varepsilon \imath \rho o \theta \varepsilon \tau \varepsilon \tilde{v} v ; \chi \varepsilon i \rho+\tau \varepsilon i$ v $\omega=$ to stretch, lengthen the hands; $\chi \varepsilon i \rho+\tau i \theta \eta \mu l=$ to lay the hands down). These terms were used interchangeably, the distinction between the two having been made only in the $8^{\text {th }}$ century. Starting then, the difference between khirotonia and khirotesia is clearly made in canonical and liturgical documents of the Byzantine Church; the first being used for the act of introduction in one of the three orders of sacramental priesthood (deacon, priest, bishop), committed in the altar, while the second term was only used for a blessing ( $\varepsilon v \lambda o$ jí $\alpha$ ), granted also through the imposition of hands, used for the act of introduction in the lower orders of sacramental priesthood (subdeacon, reader, cantor, exorcist, ostiarius), committed outside the altar ${ }^{2}$.

In the synodical and patristic canonical legislation of the first millennium, the term khirotesia ( $\chi \varepsilon \imath \rho o \theta \varepsilon \sigma i \alpha)$ signified not only the liturgical act of conferring the priesthood, but also the proper act of

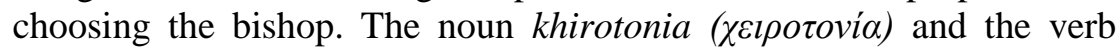

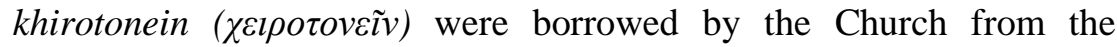
ancient pagan language, where besides the aforementioned form, also had the meaning of raising the arm to vote, to choose somebody by voting. In time, the respective terms extended their meanings, referring not only to the vote itself, but to any election, no matter how it was done, and even to the appointment of a person without an election ${ }^{3}$. Initially, the Church used those terms with the meaning of choosing, designating by election, while for placing someone on the priesthood

\footnotetext{
${ }^{2}$ Cf. C. Vogel, "Chirotonie et chirothésie. Importance et relativité du gest de l'imposition des mains dans la collation des ordres”, in Irénikon 45 (1972), pp. 10-12; and also C. Vagaggini, "L'ordinazione delle diaconesse nella tradizione greca e bizantina", in Orientalia Christiana Periodica 40 (1974), p. 170.

${ }^{3}$ Cf. Sever Buzan, "Hirotonie şi hirotesie", in Ortodoxia 4 (1957), pp. 591-592; and also F. Prat, "Evêque”, in Dictionnaire de Théologie Chatolique, t. 5, Paris, 1924, col. 1684.
} 


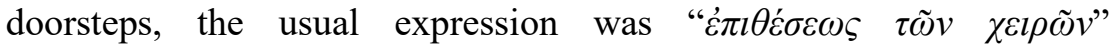
(imposition of hands: I Tim. 4, 14; 5, 22; II Tim. 1, 6; Acts 6, 6) ${ }^{4}$.

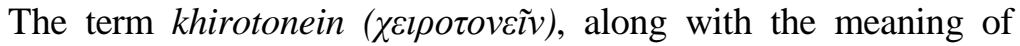
vote, also had from the early ages the meaning of consecration or ascent in an order of sacramental priesthood, probably because the election and the ordination were interdependent, the second immediately following the first ${ }^{5}$. Starting with the $2^{\text {nd }}$ century, this term began to be used more and more with the meaning of ordination to priesthood and only in extraordinary circumstances as election. With this meaning we find it in the Apostolic Constitutions (VI, 17; VII, 46) and in Didascalia (II, 2, 3) and in a series of canons: Apost., cann. 1, 2, 35, 36, 68, 82; Nicaea I, cann. 8, 16; Efes, can. 9; Chalcedon, cann. 10, 28, 30; Trullan, cann. 3, 12, 13, 17, 31. Also St. John Chrysostom defines ordination as: "This is khirotonia: put your hand on man and God commits all; His hand is the one that touches the head of the ordinand, if properly commited".

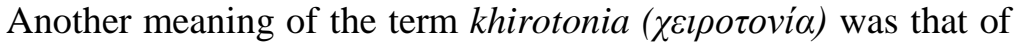
blessing through prayers and the laying on of hands by the bishop. With this meaning it is used to designate the acceptance into the inferior clergy ${ }^{7}$. Even if the same term is used, the liturgical act cannot be assimilated to the ordination itself, in the sense of priesthood, but just a simple consecration or blessing, liturgical act defined by the term

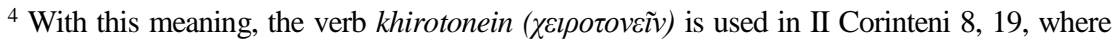
Apostle Paul is speaking of a brother "chosen ( $\chi \varepsilon i \rho o \tau o v \eta \theta \varepsilon i \varsigma)$ by the churches", meaning by the congregation of believers, to accompany him in his work. It is also utilized in Didache $(\mathrm{XV}, 1)$, and in the writings of St. Ignatius of Antioch (Letter to the Philadelphians X, 1; Letter to the Smyrnaeans X, 2; Letter to the Polycarp VII, 2), in Apostolic Constitution (VIII, 4); at St. John Chrysostom (Homily XXXII on Matthew). Cf. S. Buzan, Hirotonie şi hirotesie, pp. 592-593.

${ }^{5}$ Ibidem, p. 595

${ }^{6}$ Omilia XIV Apostles' Acts, in P.G. 60, col. 116.

7 The word "cleric" derives from the Greek noun kliros ( $\kappa \lambda \dot{\eta} \rho \circ \varsigma$ ), which means inheritance or a part of it assigned to each heir. It will enter into the ecclesiastical language quite late (about $4^{\text {th }}$ century) with the meaning, for one who had the title of cleric, of successor to one part of the inheritance left by Christ, or one whose inheritance is from Christ. Cf. Jean Gaudemet, Storia del diritto canonico - Ecclesia et Civitas, Milano, Edizioni San Paolo, 1998, p. 84. 
khirotesia $(\chi \varepsilon i \rho o \theta \varepsilon \sigma i \alpha)$. This is how the canonic provisions with respect to ordination of deaconesses must be understood (Trullan, cann. 14, 40), and the ordination of subdeacon (Trullan, can. 15).

As for the term khirotesia ( $\chi \varepsilon i \rho o \theta \varepsilon \sigma i \alpha)$, considering its meaning, this is the most appropriate to indicate the essential ceremony of Ritual of Ordination for being the seen as part of this mystery. In the beginning, the term was used with the meaning of priest's ordination, but also as blessing, generally, or blessing in the sense of promotion in the inferior clergy. In time, the meaning of priest's ordination would disappear in favor of the blessing for the inferior clergy appointment, or for granting administrative or honorary titles ${ }^{8}$.

In the canonic legislation of the first millennium, the confusion between khirotonia ( $\chi \varepsilon \imath \rho o \tau o v i \alpha)$ and khirotesia ( $\chi \varepsilon \imath \rho o \theta \varepsilon \sigma i \alpha)$ would continue, so that one would frequently be used with the meaning of the other and vice-versa until late. We find examples in the following canons: Nicaea I, can.19; Chalcedon, cann. 6, 15; Trullan, cann. 14, 15, 40; Carthage, can. 80; Neocaesarea, can. 9; Antioch, cann. 10, 17, 22; Nicephorus the Confessor, can. 6.

\section{The Bishop - the only performer of the Ritual of Ordination.}

Holy canons confirmed the Church tradition in respect to the performer of this ritual, with the attribute of only the Bishop to serve for all three orders (deacon, priest, bishop).

Yet, for the ordination to be legal and valid, the holy canons established rules in regards to the performer, as follows:

1) The ordination in the rank of bishop must be officiated by at least three bishops, or if necessary, two bishops ${ }^{9}$.

${ }^{8}$ Cf. S. Buzan, Hirotonie şi hirotesie, pp. 597, 601.

${ }^{9}$ Even if the synodical norm prevails over the apostolic norm, we still have to admit that the apostolic norm retains its validity for the fortunate cases which impede the meeting of three or more bishops. Moreover, in Apostolic Constitutions (VIII, 27, 3), it is admitted in cases of extreme necessity, that the ordination for bishop to be done by only one bishop: "If necessity requires that [one bishop] to be ordained by one bishop, with others not being able to be present because of persecution or other similar motives, then he will bring the proof of the 


\section{The Holy Sacrament of Ordination - Principles and Elements}

of Canonical Doctrine

Apost., can. 1: A Bishop must be ordained by two orthree other Bishops.

Nicaea I, can. 4: It is most fitting that a Bishop should be installed by all those in his province. But if such a thing is difficult either because of the urgency of circumstances, or because of the distance to be travelled, at least three should meet together somewhere and by their votes combined with those of the ones absent and joining in the election by letter they should carry out the ordination thereafter. But as for the ratification of the proceedings, let it be entrusted in each province to the Metropolitan.

Constantinople (394), can. 1: We enact that it shall not be permissible for a Bishop to be ordained by two, conformably to the Nicene Council.

2) The ordination in the rank of deacon is the exclusive competence of a bishop.

Apost., can. 2: A Presbyter must be ordained by a single Bishop, and so must a Deacon and other Clergymen.

3) The bishop who officiates the ordination must be legally constituted, i.e. legally ordained and is necessary to ensure the existence of apostolic succession, and not be fallen in schism or heresy (Constantinople I, can. 4; Saint Basil the Great, can. 1).

4) The eparchial bishop (or the priest delegated) has the competence to ordain only within the canonic limits of his jurisdiction and only the belonging candidates of this jurisdiction. In exceptional circumstances, but only with pre-approval from the local clergy, any canonical bishop can officiate the ritual of ordination in a different jurisdiction or on other persons belonging to different jurisdictions.

decision to more bishops". Domenico Spada - Dimitrios Salachas eds., Costituzioni dei Santi Apostoli per mano di Clemente, Roma, Urbaniana University Press, 2001, p. 232. 
Apost., can. 35: A Bishop shall not dare to confer ordinations outside of his own boundaries, in cities and, territories not subject to him. If he be proved to have done so against the wishes of those having possession of those cities or territories, let him be deposed, as well as those whom he ordained.

Antioch (341), can. 13: Let no Bishop dare to go over from one province into another and ordain any persons in church to promotion of the liturgy, even though he take others along with him, unless, having been asked to do so, he should arrive by letters of the Metropolitan and of the Bishops accompanying him, into whose district he should happen to be passing. But if, without anyone inviting him or calling him, he should depart irregularly to lay hands upon certain persons, and to meddle in the status quo of ecclesiastical affairs that do not concern him, all things whatsoever that he may do shall be null and void and invalid; and he himself shall incur a suitable sentence for his irregularity and his unreasonable proceeding, having been already deposed hence by the holy Council.

Antioch, can. 22: A Bishop shall not intrude upon another city that is not subject to his jurisdiction, nor upon a territory that does not belong to his dominion, for the purpose of ordaining anyone, or of appointing Presbyters or Deacons in regions that are subject to the jurisdiction of another Bishop, except, of course, with the consent and approval of the Bishop proper to the territory in question. If, however, anyone should dare to do such a thing, let the ordination be null and void, and let him be punished by the Synod.

Constantinople I (381), can. 2: Bishops must not leave their own diocese and go over to churches beyond its boundaries; but, [...]. Let Bishops not go beyond their own province to carry out an ordination or any other ecclesiastical services unless (officially) summoned thither. When the Canon prescribed in regard to dioceses (or administrative provinces) is duly kept, it is evident that the synod of each province will confine itself to the affairs of that particular province, in accordance with the regulations decreed in Nicaea [...]. 


\section{The Holy Sacrament of Ordination - Principles and Elements} of Canonical Doctrine

Ancyra (314), can. 13: Auxiliary Bishops shall have no right to ordain presbyters or deacons, but, moreover, not even city presbyters may they ordain, without being allowed to do so by the Bishop with letters in another diocese ${ }^{10}$.

5) The bishop is bound to comply the prescribed order for ordination, and to not ordain in a superior order before the candidate first received the previous order. Also, he must observe the interstitial periods and not ordain a person into deacon, priest and bishop at the same liturgy ${ }^{11}$.

Sardica, can. 10: Due care must be taken to investigate with all accuracy and diligence so that, if any rich man or man of eloquence from the forum should demand to be made a Bishop, he shall not be appointed unless he first performs services of an Anagnost, and of a Deacon, and of a Presbyter, in order that, if he be deemed worthy with respect to each grade, he may progress by promotion to the apex of the episcopate. The grade, this means, in each rank shall not be of too short a length of time to enable his faith and the kindliness of his manners, and his solidity, and his blandness to become patent, and he himself, after being deemed worthy of holy orders, shall enjoy the highest honor [...].

Constantinople (861), can. 17: Since we have been occupied with matters of ecclesiastical good order, it behooves us to decree also this, that henceforth none of the laymen or monks shall be allowed to ascend to the height of the

\footnotetext{
${ }^{10}$ It is about the so called "Litterae dimissoriae", which permitted not only the chorbishop, but any provincial bishop to ordain candidates outside their canonical jurisdiction. That norm is repeated in canon 10 of the local council of Antioch (341).

${ }^{11}$ In the same day, before the liturgy, a person can also be ordained (khirotesia) lecturer and subdeacon, so that he may be ordained deacon during the subsequent liturgy. Additionally, more subdeacons can be ordained at the same time; however, no more than one person can be ordained during the liturgy.
} 
episcopacy precipitately and multitudinously as in a stampede, but, on the contrary, by being duly examined with reference to the various ecclesiastical degrees or grades, let them thus attain to ordination to the episcopacy. For even if hitherto and up till now some laymen and some monks, owing to need or want demanding it, have been enabled to attain to the honor of the episcopate immediately and without further ado, and they have distinguished themselves for virtuousness and have exalted their churches, yet the fact is that what is of rare occurrence cannot be made a law of the Church; we therefore decree that this shall no longer be done hereafter and henceforth, but that the ordinate must pass through the priestly degrees in a logical manner by fulfilling the required length of service of each order before proceeding to the next higher rank.

6) All ordinations must be done with a specific destination, otherwise they are invalid.

Chalcedon, can. 6: It is decreed that no one shall be ordained at large either a Presbyter or a Deacon, nor anything else at all in the ecclesiastical ranks unless he be particularly assigned to the church of some city, or to a martyry, or to a monastery. As for those ordained at large the holy Council has

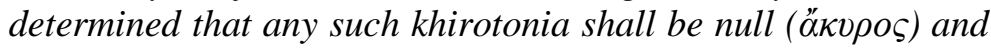
void, and that such ordinees shall not be allowed to officiate anywhere, to the dishonor of the ordainer ${ }^{12}$.

\footnotetext{
12 The canon established the principle that every cleric must be ordained with a specific destination, being unable to exercise his ministry anywhere other than the Church through which he was ordained. The synodal provision applies, according to Theodor Balsamon, not only to the priests and deacons, but to everyone in the clerical registry, including the superior and inferior clergy (Cf. Nicodim Milaş ed., Canoanele Bisericii Ortodoxe însoţite de comentarii, vol. I, 2, Arad, Diecezana Press, 1931, p. 202). Also see the apostolic canons 15 and 16, as well as canon 10 of the Chalcedon synod, which prevent the clergies from functioning at the same time in other Churches.
} 
To all this prescriptions in regards to the performer of the ritual, we must add the one established by apostolic canon 68, which forbids the repeat of ordination, out of the case when the performer was proven as heretic ${ }^{13}$.

Apost., can. 68: If any Bishop, or Presbyter, or Deacon accepts a second ordination from anyone, let him and the one who ordained him be deposed. Unless it be established that his ordination has been performed by heretics. For those who have been baptized or ordained by such persons cannot possibly be either faithful Christians or clergymen ${ }^{14}$.

On the same stance are the Apostolic Constitutions, which consider ordinations officiated by heretics to be null and void and those ordained by them cannot be considered priests (Apost. Const. VI, 15, 3 ). The bishops or priests who fall into heresy or schism lose the status of clergy, falling out of divine grace, but the ordinances they have officiated previous to the fall in heresy or schism remain valid (Apost. Const. VIII, 2, 4-6). Furthermore, the ordinations officiated by bishops under the defrocking punishment or deposition are also invalid.

The antic norm invalidates any ordination made by traffic of influence or nepotism, punishing the offender of such an attempt by excommunication. The principle is consecrated in the apostolic canon 76, which orders: "It is decreed that no Bishop shall be allowed to ordain whomsoever he wishes to the office of the Episcopate as a matter of concession to a brother, or to a son, or to a relative. For it is not right for heirs to the Episcopate to be created, by subjecting God's things to human passion; for God's Church ought not to be entrusted to heirs. If anyone shall do this, let the ordination remain invalid and void, and let the bishop himself be penanced with excommunication".

${ }^{13}$ Actually, ordination is repeated not only when it is found that the performer is heretic, but also whenever the ordination is deemed invalid, in the sense presented by the canons.

${ }^{14} \mathrm{We}$ find the same ordinance in can. 48 of the local synod of Carthage. 


\section{The subject of Holy Orders}

Even if the sacred canons are talking about ordination (khirotonia/khirotesia) of women in the rank of deaconess (Trullan, cann. 14, 40), the Church complied from the beginning to the teachings of Christ, who did not give the divine grace of apostolate other than men. It has established that the beneficiary of the Holy Ordination can be any Christian male with sacerdotal vocation, satisfying fundamental religious conditions, physical, moral and intellectual.

1) Fundamental conditions: sex male, valid baptism, right faith. The canon 10 of Nicaea I (325) stops the entry into clergy those who had previously withdrawn from the right faith and then re-entered, and also punishes by defrocking those who knowingly or unknowingly entered into clergy.

2) Physical conditions: body integrity, age.

Body integrity doesn't mean the total absence of physical defects, but merely lack of physical traits necessary to perform priestly duties. The canons do not forbid one worthy of receiving the ordination if he has a missing limb or sense which does not affect his priestly duties.

Apost., can. 77: If any cripple, or anyone with a defect in an eye or in a leg, is worthy of the episcopate, let him be made a bishop. For it is not an injury to the body that defiles one, but a pollution of the soul.

However, for the one who has lack of senses, the canons forbid him from entering into clergy.

Apost., can. 78: Let no one that is deaf nor anyone that is blind be made a Bishop, not on the ground that he is deficient morally, but lest he should be embarrassed in the exercise of ecclesiastical functions.

This norm does not refer to those who lose their senses after entering the clergy. Commenting this canon, Theodor Balsamon believes 
that people like this do not lose their priesthood, but only their right to exercise $\mathrm{it}^{15}$.

The sacred canons also forbid entering into clergy, or continuing to officiate, if they are members of the clergy already, for those who by own will have mutilated themselves.

Nicaea I, can. 1: If anyone has been operated upon by surgeons for a disease, or has been excised by barbarians, let him remain in the clergy. But if anyone has excised himself when well, he must be dismissed even if he is examined after being in the clergy. And henceforth no such person must be promoted to holy orders. But as is self-evident, though such is the case as regards those who affect the matter and dare to excise themselves, if any persons have been eunuchized by barbarians or their lords, but are otherwise found to be worthy, the Canon admits such persons to the clergy.

Sacerdotal ministry requires responsibility and maturity, the reason for which the Church has imposed from the very beginning an age limit for each one of the priesthood ranks. In the Apostolic Constitutions we find the first provisions regarding the canonical age required for admission in the rank of bishop. It required the minimum age of 50 for candidates for bishop, with the norm not being absolute, because a younger age was allowed under exceptional circumstances.

Apost. Constit., II, 1: (1) But concerning bishops, we have heard from our Lord, that a pastor who is to be ordained a bishop for the churches in every parish, must be unblameable, unreprovable, free from all kinds o wickedness common among men, not under fifty years of age [...]. (3) But if in a small parish one advanced in years is not to be found, let some younger person, who has a good report among his neighbors, and is esteemed by

15 Cf. Constantin Dron, ed., Canoanele - text şi interpretare, I, Canoanele Apostolice, Bucuresti, Tipografia Cărţilor Bisericeşti, 1933, pp. 245-246. 
them worthy of the office of a bishop, who has carried himself from his youth with meekness and regularity, like a much elder person, after examination, and a general good report, be ordained in peace. (4) For Solomon at twelve years of age was king of Israel, and Josiah at eight years of age reigned righteously, and in like manner Joash governed the people at seven years of age ${ }^{16}$.

During the Emperor's Justinian reign the canonical age for bishop's ordination was reduced to 35 (Novella 123,1) and later to 30 (Novella 137, 2; Basilicals 3, 1, 8). For the rank of priesthood, the canons established the age of 30, for deacon 25, and for subdeacon 20. In case of failure to implement the canonic age for ordination, the Fathers of Trullan disposed defrocking.

Neocaesarea, can. 11: Let no man be ordained a Presbyter before he is thirty years old, even though the man be worthy in every other respect, but let him be obliged to wait. For the Lord Jesus Christ was baptized and commenced teaching in His thirtieth year.

Carthage, can. 16: It has pleased the Council to decree that Deacons shall not be ordained before the age of twenty-five.

Trullan, can. 14: Let the Canon of our holy and Godbearing Fathers be observed also in respect to this, that a Presbyter may not be ordained before he is thirty years old, though the man be thoroughly worthy; but, instead, let him be obliged to wait. For our Lord Jesus Christ was baptized when He was thirty years old, and then He began teaching. Likewise, let no Deacon be ordained before he is twenty-five years old, nor a Deaconess ${ }^{17}$ before she is forty years old.

Trullan, can. 15: Let no one be ordained a subdeacon if he is less than twenty years old. If anyone should be ordained in any

${ }^{16}$ Constit. Apost. II, 1, 1, 3-4, in Domenico Spada - Dimitrios Salachas eds., Costituzioni dei Santi Apostoli per mano di Clemente, p. 11.

${ }^{17}$ The same age is also provided in canon 15 of the Chalcedon ecumenical council. 


\section{The Holy Sacrament of Ordination - Principles and Elements}

of Canonical Doctrine

sacerdocy whatever without having reached the years decreed, let him be deposed from office.

The ancient norms also establish the lecturers' consecration, setting minimum age at 18 years old (Carthage, can. 16; Novella 123; Basilicals 2, 1, 25).

3) Moral conditions: impeccable moral behavior for the priesthood candidate as well for his wife. The canons demand for the ordained candidate an impeccable moral behavior, not allowing the entry into clergy of those with immoral conduct or those who got into a forbidden second marriage, or persons with a life incompatible with the priestly mission. Also, those who are going to marry after entering the clergy, or felt into the sin of fornication, are forbidden from the ministry.

Apost., can. 17: Whoever has entered into two marriages after baptism, or has possessed himself of a concubine, cannot be a Bishop, or a Presbyter, or a Deacon, or anything else in the Sacerdotal List.

Apost., can. 18: No one who has taken a widow, or a divorced woman, or a harlot, or a house maid, or any actress as his wife, may be a Bishop, or a Presbyter, or a Deacon, or hold any other position at all in the Sacerdotal List.

Apost., can. 19: Whoever marries two sisters, or a niece, may not be a clergyman.

Apost., can. 61: If a charge of fornication, or of adultery, or of any other forbidden act be brought against a faithful one, and be proved, let him not be promoted to the clergy.

Trullan, can. 3: Whereas our Pious and Christ-loving Emperor, in his address to this holy and Ecumenical Council, has suggested that those enlisted the Clergy and conveying to others the Divine truths should be pure and faultless ministers, and worthy of the intellectual sacrifice of the great God and victim and high priest, and eliminate the hatred due to friction resulting from illicit marriages; [...] therefore we concur in decreeing that, as 
regards bigamists who have been enslaved to sin and have not chosen to recede therefrom, as of the fifteenth day of the month of January last past, in the last fourth Indiction, in the year six thousand one hundred and ninety, they are to be subjected to canonical deposition; but as for those bigamists who have taken cognizance of their own interest before we had notice of their doing anything wrong, and who cut out the evil besetting them, and chased this foreign and spurious engagement far away; or even those whose wives by a second marriage have died, if they too have seen their way to return to good sense after later learning sobriety, and have quickly come to forget their former misdeeds and violations of the law, whether they happen to be Presbyters or Deacons - it has seemed best to us for these men to be dismissed from every sacerdotal office, or priestly activity, having already been penanced for an express length of time. But we have decided that in the case of those who have committed the iniquitous act unwittingly and who are weeping to the Lord to be pardoned therefore, they deserve to share in the honor of standing and sitting in the place reserved for the presidency: for to bless one that ought to take care of his own wounds is inconsistent. But, on the other hand, as for those who have contracted but one marriage, and this with a woman that was a widow, and likewise as for those who after ordination have involved themselves in an illegal marriage, ${ }^{i}$ that is to say, Presbyters and Deacons and Subdeacons, not long ago excluded from the sacred liturgy and penanced, we order them to be restored to their former ranks, without being in any way promoted to any higher rank, it being obvious that their illegal marriage has been dissolved. We have made these decrees effective as of the said fifteenth day of the month of January, in the fourth Indiction, in regard to those guilty of the offenses before specified and in priestly offices; but besides this we henceforth decree and renew the Canon prescribing that anyone who has become involved in two marriages after baptism, or has acquired a concubine, "cannot become a Bishop, or a Presbyter, or a Deacon, or anything else in the roll of the priesthood. Likewise, in regard to anyone that has taken a widow, 
or a divorcee, or a harlot, or house servant, or an actress to wife, we decree that he cannot be a Bishop, or a Presbyter, or a Deacon, or anything else in the roll of the priesthood.

Trullan, can. 26: As for a Presbyter who has unwittingly entangled himself in an unlawful marriage, let him retain his rights to sitting with his rank, in accordance with what has been prescribed to us as legislation by the sacred Canon, but let him refrain from the rest of functions and activities. For a pardon is sufficient for him; but for him to bless another person when he ought to be looking after his own wounds, is inconsistent: for blessing is the impartation of sanctification. But how can one who lacks this, on account of his lapse as a result of ignorance, impart it to another? Let him therefore bless no one either publicly or privately; neither let him distribute the body of Christ to others, nor perform any other liturgical office. On the contrary, while contenting himself with the presidency, let him persistently weep to others, and to the Lord, to be pardoned for the iniquitous deed which he has unwittingly perpetrated. For it is obvious that any such unlawful marriage must be dissolved, and that the man will have no essential share in the sacred office of which he has been deprived.

Neocaesarea, can. 1: If a Presbyter gets married, he is displaced from orders; but if he commit fornication or adultery, he must be ousted altogether, and be led to repentance.

Neocaesarea, can. 8: When the wife of a layman commits adultery, if she has been convicted openly of this offense, that layman cannot enter the service. If, on the other hand, she commits adultery after his ordination, he must divorce her. But if he continues to live with her, he cannot retain possession of the office which has been placed in his hands.

Neocaesarea, can. 9: If any Presbyter who has committed a bodily sin beforehand has been promoted, and confesses that he sinned before his ordination, let him not offer the oblation, but let him remain in other respects for the rest of his course. For most persons would forgive the other sins, and let the ordination go. But 
if he fails to confess but is openly proved guilty, let him have no authority to exercise that function on any account.

Neocaesarea, can. 10: Likewise, if a Deacon falls into the same sin, let him keep the rank of servant.

St. Basil the Great, can. 12: The Canon has unconditionally excluded from the service all digamists (i.e., men that have married twice).

With these impediments, the holy canons forbid the entering into clergy or continue officiating for the following deeds: witchcraft (Gregory of Nyssa, can. 3; Basil the Great, cann. 65, 72), bribery for entering the clergy (Apost., can. 29; Chalcedon, can. 2; Trullan, cann. 22, 23; Nicaea II, cann. 4, 5, 15, 19; Basil the Great, can. 90; Ghennadios, Epistle about simonie; Tarasius, Epistle about simonie), intentional or unintentional killing (Gregory of Nyssa, can. 5), appropriation of property (Apost., can. 25; Basil the Great, can. 61), usury (Apost., can. 44; Nicaea I, can. 17; Trullan, can. 10; Laodicea, can. 4; Carthage, cann.5, 16; Gregory of Nyssa, can. 6; Basil the Great, can. 61), perjury (Apost., can. 25; Basil the Great, cann. 64, 82).

\section{4) Intellectual conditions}

Since the apostolic times, the intellectual preparation was one of the basic requirements for those aspiring clergy. Therefore, St. Paul was listing, among other qualities required for a bishop, that one of wisdom and skill to teach others (I Tim. 3, 2; Tit 1, 9), so he disposed for the priests who labor with word, to teach others, to get double honors (I Tim. 5, 17), obviously, qualities acquired by effort and serious intellectual formation. In Apostolic Constitutions were required, besides age, an intellectual preparation or formation at the level of their respective society and era (Apost. Const., II, 1,2). The respective norm will be resumed in canon 2 of the $7^{\text {th }}$ ecumenical council from Nicaea (787), requiring the bishops a solid theological (Holy Scripture and Psalter) and canonical (sacred canons) knowledge.

Nicaea II, can. 2: Since as a matter of fact we are binding ourselves to God by chanting: "I will meditate in thy rights; I will not forget they words" (Ps. 118, 16), it behooves all Christians to 


\section{The Holy Sacrament of Ordination - Principles and Elements}

of Canonical Doctrine

keep this for their own salvation, but more eminently so those invested with a sacerdotal dignity. Hence we decree that anyone who is about to be promoted to the rank of bishop shall by all means know the psalter, in order that he may be able to admonish all the clergy about him to become initiated; and that he be scrupulously examined by the metropolitan as to whether he is cheerfully willing to read searchingly and not cursorily the sacred Canons and the holy Gospel, the book of the divine Apostle, and all the divine Scripture, and in accordance with the divine commandments to hold intercourse with and teach the laity about him. For the essentiality of our prelacy is the words taught by God, or, at any rate, the true science of the divine Scriptures, just as great Dionysius declared. But if he should be in doubt, and not care to do and teach thus, he must not be ordained. For God has said prophetically: "Because thou hast rejected knowledge, I will also reject thee from acting as my priest" (Hos. 4:6).

Since the time of Emperor Justinian, was willing that bishops, because their very important role in politics as well, to be well prepared. Private theological schools or churches, existing since the $2^{\text {nd }}$ century in centers like Alexandria or Antioch, and later Constantinople, demonstrates the constant concern of the Church to have a well prepared clergy to all levels, theological and profane culture alike.

\section{Ordination of women (deaconesses)}

In Apostolic Constitutions (380) it argues why women cannot be subject of the Priesthood Mystery as follows:

Apostolic Constitutions III, 9, 2-4: (2) For if the "man be the head of the woman", and he be originally ordained for the priesthood, it is not just to abrogate the order of the creation, and leave the principal to come to the extreme part of the body. For the woman is the body of the man, taken from his side, and subject to 
him, from whom she was separated for the procreation of children. For says He, "He shall rule over thee". For the principal part of the woman is the man, as being her head. (3) But if in the foregoing constitutions we have not permitted them to teach, how will anyone allow them, contrary to nature, to perform the office of a priest? For this is one of the ignorant practices of the Gentile atheism, to ordain women priests to the female deities, not one of the constitutions of Christ. (4) For if baptism were to be administered by women, certainly our Lord would have been baptized by His own mother, and not by John; or when He sent us to baptize, He would have sent along with us women also for this purpose. But now He has nowhere, either by constitution or by writing, delivered to us any such thing; as knowing the order of nature, and the decency of the action; as being the Creator of nature, and the Legislator of the constitution ${ }^{18}$.

The fact that the woman does not have the sacerdotal vocation is confirmed by the Fathers of local synod of Laodicea (343-381), who in canon 44 do not allow women to enter the altar ${ }^{19}$. The same Apostolic Constitutions (III, 6), along the Pauline letters (I Cor. 14, 34-35; I Tim. 2, 11-12) and Didaskalia (cca. 230), also forbade women to teach and preach in Church ${ }^{20}$, arguing: "(1) We do not allow women to teach in

${ }^{18}$ Constit. Apost. III, 9, 2-4, in D. Spada - D. Salachas eds., Costituzioni dei Santi Apostoli per mano di Clemente, pp. 85-86.

19 A norm that would thereafter be extended upon all the laity through canon 69 of the Trullan synod (691) is that which signifies that the altar was the sacred place designated only for the clergy.

${ }^{20}$ As far as I Corinthians 14, 34-35 is concerned, in which woman is forbidden from taking the word in the liturgical assembly, some authors such as J. Leipold and A. Feuillet believe that the verses in question are interpolations since they are in contradiction with Corinthians 11,5 , which states that woman who prays or prophetizes must have her head covered. Therefore, it is possible that the respective provisions had been added by one who had gathered the Apostle's letters and were along the same lines as those from Timothy 2, 11-15, in which woman, created after man and through which sin was introduced to the world, is forbidden from learning, only needing to "teach herself in silence, with complete subjection". J. Leipold, Die Frau in der antiken Welt und im Urchristentum, Gütersloch, 1962, p. 126; A. Feuillet, "La dignité et rôle de la femme d'après quelques textes pauliniens: comparaison avec l'Ancien Testament”, in New Testament Studies, n. 21 (1975), pp. 162-170. 
the Church, but only to pray and listen to the teachers. (2) Our Savior Jesus Christ when He sent us, all thirteen of us, to teach the (Jewish) people and all the peoples, in no way has he sent women to preach, although women were present. With us were Virgin Mary and her sisters, Mary of Magdala and Mary, Jacob's mother, Martha and Mary, Lazar's sisters, Salome and others. If it were necessary for women to teach, He would have been the first to order them to instruct the people along with us. In fact, if the woman's head is the man, is not right for the rest of the body to order to the head"21.

The Fathers of Trullan council (691), reaffirming the ancient practice, did not allow to the women to preach during liturgy (canon 70). This interdiction, founded on the words of Apostle Paul from I Corinthians 14, 34-35, was due in fact to the Gnostics and various sects, as the Montanists, which were offering women a privileged liturgical position, approving sacerdotal positions for them ${ }^{22}$.

Even if the Church's belief is that woman does not have sacerdotal vocation, the figure of deaconesses from the ancient Church and their role in the liturgical and Church life of the first Christian communities is not well defined even today ${ }^{23}$. In the Byzantine tradition, however, the liturgical ritual for the deaconess' ordination looked very much alike the one used for ordination of deacons, priests and bishops. The $8^{\text {th }}$ century Barberini Code (Greek) 336 gives us a lot of information about this: ordination was taking place after Anaphora (as in the deacon's ordination), the one who was to be ordinated was being accompanied to the bishop, in the altar, where he was laying hand

${ }^{21}$ Constit. Apost. III, 6, 1-2, in D. Spada - D. Salachas eds., Costituzioni dei Santi Apostoli per mano di Clemente, pp. 82.

22 Bishop Firmilian of Caesarea, in a letter addressed to St. Cyprian of Carthage, speaks of some women, Montanist prophetesses, committing the Eucharist mystery. And Ambrosiaster shows that Quintillians (Montanists) claimed the authority of the sacerdotal ministry for the women. (PL 17, col. 496). Cf. Pietro Sorci, "Ministeri liturgici della donna nella chiesa antica”, in Cetinna Militello ed., Donna e ministero, Roma, Edizioni Dehoniane, 1991, p. 19, n. 4.

${ }^{23}$ Cf. Dimitrios Salachas, Il Diritto Canonico delle Chiese orientali nel primo millennio, Roma-Bologna, Edizioni Dehoniane, 1997, p. 233. 
on her, committing the ritual of ordination, the same for ordination of deacons, priests and bishops ${ }^{24}$. Moreover, canon 15 of Chalcedon and canon 44 of Basil the Great, referring to deaconesses, do not use the feminine noun "deaconess", but masculine noun "deacon". The same canon 15 of Chalcedon establish the same matrimonial impediment for deaconess as for bishops, priests and deacons ${ }^{25}$.

\section{Effects of legal-canonical ordination}

Ordination determines a set of legal-canonical effects regarding the sacerdotal structure and also clergy's marital status, as follows:

1) the one who receives the ordination gets the status of cleric, becoming member of the hierarchy of divine establishment with all rights and duties in the rank he was ordained for;

2) the ordination for any rank, if validated, has indelible properties and cannot be repeated for the same hierarchical level ${ }^{26}$;

3) a valid ordination is personal, grace received and the right to exercise the religious power in the rank for which was ordained, are proper for that person only;

4) once validated for the clergy, this status cannot be rescinded $^{27}$;

5) the one who received the ordination cannot get married or re-marry ${ }^{28}$.

${ }^{24}$ Cf. P. Sorci, Ministeri liturgici della donna nella chiesa antica, p. 65.

${ }^{25}$ Cf. D. Salachas, Il Diritto Canonico delle Chiese orientali nel primo millennio, p. 233.

${ }^{26}$ St. Cyprian of Carthage compares ordination with baptism, showing how important the two mysteries are: baptism introduces the person into the Church's body, and ordination into the elected servants of the Church; what both acts have in common is the fact that they cannot be repeated (S. Ciprian, De ablut. ped., c. 27). Cf. N. Milaş, Dreptul bisericesc oriental, Bucuresti, Tipografia Gutenberg 1915, p. 229.

${ }^{27}$ Canon 7 Chalcedon establishes that one who enters the clergy and then leaves priesthood, embracing worldly jobs, should be anathematized.

${ }^{28}$ Canon 6 Trullan states in this respect: "Neither the subdeacon, nor the deacon, nor the presbyter can marry after ordination; one who dares to do so must resign". Therefore, that one who wants to marry, must do so before ordination in the order of subdeacon, although Apostolic canon 26 was allowing the readers and the cantors to get married after being appointed. In contrast with apostolic norm, canon 10 Ancira (314) allowed the deacon's 
6) the one who receives the ordination has the obligation to obey the canonical discipline towards the clergy authorities ${ }^{29}$.

In conclusion, being considered one of the most important mysteries of the Church, the Holy Sacrament of Ordination (khirotonia

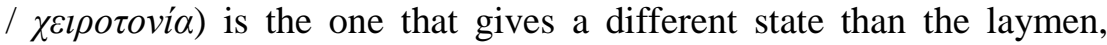
instituting the person in the ranks of superior clergy (deacon, priest, bishop). In this respect it is different from the khirotesia ( $\chi \varepsilon \imath \rho \circ \theta \varepsilon \sigma i \alpha)$, reserved for instituting in the lower ranks of sacramental priesthood. The (seen) performers of this mystery are the bishops, which in the case of ordination for the rank of bishop, must be in pair, and for the other ranks only one is necessary, provided he meets the canonical conditions which validate the act (legal constituency, apostolic succession, competency, obeying the prescribed order and interstitial periods, not being heretic or schismatic) and the ordination being made with precise destination. Also, the Oriental normative nullifies those ordinations made by traffic of influence or nepotism. The ordained ones must be only males, meeting the religious, physical, moral and intellectual conditions established in ancient synodal and patristic legislation.

marriage after ordination, in the case he declared at ordination his intention to get married. In contrast, for the presbyter who dared to marry, canon 1 Neocaesarea (314-319) decreed withdrawal from clergy. Apparently, the practice of Ancyra has not disappeared but become rather widespread among priests, so that, although the Trullan norm was quite common, in the year 867 Leo VI the Philosopher (886-912), through Novella 3, prohibits the practice of giving the deacons and priests a two-year period after ordination, during which they could conclude a legal marriage. In 1923 the Panorthodox Congress in Constantinople, taking into consideration the fact that all listed canons are norms without a dogmatic basis, decided that each local Church (council) could, under special circumstances, grant exemptions for the marriage and remarriage of the parish clergy. The Holy Synod of the Orthodox Church appropriated the Panorthodox decisions of 1923 and ordered in Decision no. 5116/1952 that the situation of priests and deacons widowed by the death of their wives and who want to remarry should be left to each individual bishop to solve on a case by case basis, in the spirit if church canons and norms. Currently, this situation is clearly handled in Decision no. 1092 /11.02.2010.

${ }^{29}$ For the clergy that slanders or refuses to obey their own bishop, the holy canons prescribe punishment by defrocking. See: Apost., cann. 31, 55; Chalcedon, can. 8; Sardica, can. 14; III Constantinople, can. 13. 
Therefore, women are absolutely excluded from receiving this mystery, not being considered as having sacerdotal vocation. Thru its administration, the ordination determines canonical legal effects which implies a special statute, imposing an appropriate behavior suitable to that st atus and rank.

\section{References:}

1. Buzan, Sever, "Hirotonie şi hirotesie”, in Ortodoxia 4 (1957), p. 586-611.

2. Dron, Constantin, Canoanele - text şi interpretare, I, Canoanele Apostolice, Bucuresti, Tipografia Cărţilor Bisericeşti, 1933.

3. Feuillet, Andre, "La dignité et rôle de la femme d'après quelques textes pauliniens: comparaison avec l'Ancien Testament”, in New Testament Studies, n. 21 (1975), p. 157-191.

4. Gaudemet, Jean, Storia del diritto canonico - Ecclesia et Civitas, Milano, Edizioni San Paolo, 1998.

5. Leipold, J., Die Frau in der antiken Welt und im Urchristentum, Gütersloch, 1962.

6. Migne, Jacques-Paul, Patrologiae cursus completus: series graeca, tom 60, Parisiis, 1857, 1863.

7. Milaş, Nicodim, Dreptul bisericesc oriental, Bucureşti, Tipografia Gutenberg, 1915.

8. Idem, Canoanele Bisericii Ortodoxe însoţite de comentarii, vol. I, 2, Arad, Diecezana Press, 1931.

9. Prat, F., "Evêque", in Dictionnaire de Théologie Chatolique, t. 5, Paris, 1924, col. 1684.

10. Salachas, Dimitrios, Il Diritto Canonico delle Chiese orientali nel primo millennio, Roma-Bologna, Edizioni Dehoniane, 1997.

11. Sorci, Pietro, "Ministeri liturgici della donna nella chiesa antica”, in Cetinna Militello ed., Donna e ministero, Roma, Edizioni Dehoniane, 1991, p. 17-30.

12. Spada, Domenico - Salachas, Dimitrios eds., Costituzioni dei Santi Apostoli per mano di Clemente, Roma, Urbaniana University Press, 2001. 
The Holy Sacrament of Ordination - Principles and Elements of Canonical Doctrine

13. Vagaggini, C., "L'ordinazione delle diaconesse nella tradizione greca e bizantina", in Orientalia Christiana Periodica 40 (1974), p. 145189.

14. Vogel, C., "Chirotonie et chirothésie. Importance et relativité du gest de l'imposition des mains dans la collation des ordres", in Irénikon 45 (1972), p. 7-21. 